\title{
CTSG wt Allele
}

National Cancer Institute

\section{Source}

National Cancer Institute. CTSG wt Allele. NCI Thesaurus. Code C104054.

Human CTSG wild-type allele is located in the vicinity of $14 \mathrm{q} 11.2$ and is approximately $3 \mathrm{~kb}$ in length. This allele, which encodes cathepsin G protein, is involved in protein processing and degradation. 